\title{
Vaginal Cancer pNX TNM Finding v7
}

National Cancer Institute

\section{Source}

National Cancer Institute. Vaginal Cancer pNX TNM Finding v7. NCI Thesaurus. Code C89467.

Vaginal cancer in which regional lymph nodes cannot be assessed. (from AJCC 7th Ed.) 